\title{
Reckoning Informal Politics: Expands the Logic of Survival and Failure of Regional Heads
}

\author{
Wawan Sobari Universitas Brawijaya, Indonesia
}

\begin{abstract}
The qualitative research addresses the political logic of why and how the incumbents succeed and fail in direct election for regional heads (pilkada) in emerging democratic Indonesia. De Mesquita et al. (2003) believe that, to survive in office, a leader needs to offer a benefit at least equal to the greatest possible benefit offered by a potential challenger. Particular to the pilkada cases in Indonesia, Erb and Sulistiyanto (2009) elaborate several factors connected to "reward and punishment" logic that may lead to the incumbents' survival and failure in re-election bids. This study expands the logic by revealing that populism, rivalry, and tangibility are the core strategies for the successful incumbents in retaining their offices in four rural and urban regions in East Java. Particularly, the survival of an incumbent hinges on his capacity to manage rivalry risks, namely the capability to manage support and opposition both from formal and informal actors through fair or unfair means. These strategies, then, foster the success of patronagebased winning tactics to retain public office in the pilkada. To better assessment, it calls for the importance of democratic accountability as a complementary perspective (to consolidology) in measuring the progress of democracy in the country.
\end{abstract}

Keywords:

Political Survival; Pilkada; Democracy; Indonesia

\section{INTRODUCTION}

Absolute access, wide personal networks, and rampant power abuse are common perceptions of incumbents ${ }^{1}$ in

\footnotetext{
Wawan Sobari is senior lecturer of politics and public policy at Universitas Brawijaya, head of Master Program of Social Science at Universitas Brawijaya, and senior scholar at the Jawa Pos Institute of Pro-Otonomi (JPIP). $\mathrm{He}$ can be reached at Universitas Brawijaya JI. Veteran Malang 65145, East Java, Indonesia. E-mail: wawansobari@ub.ac.id

This article is part of my doctoral thesis at Flinders University and I would like to deliver my sincere gratitude to Assoc. Professor Janet McIntyre and Craig Matheson, PhD; the Minister of Research, Technology, and Higher Education of the Republic of Indonesia (Kemenristek Dikti), and Universitas Brawijaya for providing academic and grant supports. The fieldwork was supported by Flinders University overseas field trip grant. My thankfulness is also delivered to Aribowo, MA and Airlangga University Press allowing me to publish this article. The author also wishes to thank my anonymous reviewers for their critical and encouraging comments. The content of the article and the views and opinions it contains is the author's entire responsibility.
}

contemporary local politics in Indonesia.

Incumbents have direct access to local policy making as well as local budgeting processes. They can drive budget allocation and disbursement in favour of their own interests. Incumbents also have greater opportunities to link with many influential people, organisations, and communities and undertake intensive communication to develop political alliances. $^{2}$ Incumbents can act as patrons

\footnotetext{
${ }^{1}$ Throughout the study, the term incumbent refers to the regional head (regent or mayor) occupying the office during a re-election bid.

2 As remarked by some political observers, see Yuwono (Suara Merdeka, 21 September 2010), Yazid (Rakyat Merdeka, 21 January 2011)
} 
by disbursing exclusive benefits to their clients. Moreover, incumbents have the influence to mobilise bureaucracy ${ }^{3}$ as well as to intervene in regional election commissions (Komisi Pemilihan Umum Daerah/KPUD) and regional election supervisory committees (Panitia Pengawas Pemilu/Panwaslu) to support their candidatures. ${ }^{4}$

\footnotetext{
3 As remarked by some political observers, see Harun (Rakyat Merdeka, 26 September 2010), Sobari (Jawa Pos, 18 May 2010). Also, Indonesia Corruption Watch (ICW) revealed 54 cases of bureaucracies' involvement in the 2009 pilkada in four regions (Jawa pos, 18 May 2010). General Elections Supervisory Board (Bawas/u) found also 1,751 violations in the 2010 pilkada (Source: http://us.nasional.news.viva.co.id/news/read/1952 59-2010--ada-1-751-pelanggaran-di-pilkada
} accessed on 31 May 2013) and 1,221 violations in the 2011 pilkada (Source: http://news.detik.com/read/2011/06/16/175735/ 1662013/10/bawaslu-terima-1221-pelanggaranselama-pilkada-2011 accessed on 31 May 2013). Relating to the bureaucracies' involvement, Bawaslu revealed two main modus, namely bureaucracy's mobilization to support the incumbents and the deployment of state owned facilities for the incumbents' campaigns. According to the existing regulations, the involvement of civil servants in pilkada is strictly prohibited. The government issued two regulations relating to this restriction, namely the Instruction of Administrative Reform Minister No. 7/2009 on the Neutrality of Civil Servants in Election and the Instruction of Home Minister No. 270/4627/SJ on Instruction to Governor and Regional Head to Assure Civil Servants' Neutrality in pilkada.

${ }^{4}$ As remarked by some political observers, see Rangkuti (Koran Jakarta, 30 June 2010), Badoh (Media Indonesia, 8 January 2010). Some recent legal evidence of local election commission's violations was proven by the Election Organizers Ethics Council (DKPP). For instance, the council dismissed all of the Pamekasan General Election's Commissioners due to impartiality violation (Source: http://www.antarajatim.com/lihat/berita/100318/k pu-pamekasan-hormati-keputusan-dkpp accessed
Four previous studies of direct election for local leaders (Pemilihan Kepala Daerah/Pilkada) in Indonesia confirm these points. The incumbents have remained longer in office than the contenders, have control over the bureaucracy, policy formulation and program implementation and gain better mass media self-coverage. These privileges advantage the incumbents when running in the pilkada. Besides, the incumbents gain benefits from their position to build personal patronage networks with informal actors, namely business communities, religious leaders, partisan mass media, local politicians and/or local legislators, gangsters, partisan NGOs, and mass-based organisations (Sulistiyanto, 2009; Schiller, 2009; Ratnawati, 2009; Hidayat, 2009).

As office holders, incumbents have access to complete information about government finance and budgets. This privilege is an important resource for taxsetting that is useful for incumbents to boost their performance credit amongst

on 31 May 2013). The council dismissed also three of five commissioners of the Municipality of Gorontalo General Election Commission due to similar violation (Source: http://www.jpnn.com/read/2013/03/07/161669/ DKPP-Copot-Tiga-Komisioner-KPU-KotaGorontalo- accessed on 31 May 2013). 
voters (Besley and Case, 1995). In addition, incumbents' governments can play power games to set grant policies as a vote-purchasing effort (Dahlberg and Johansson, 2002).

Although incumbents ${ }^{5}$ have advantages during office, the re-election results do not automatically favour them. According to the Indonesia Survey Circle $(\angle S /$ )'s compiled reports, the number of failed incumbents in the pilkada has increased in the first five years (20052010). From June 2005 to December 2006, 87 of 230 incumbents (37.83\%) did not succeed in retaining office as a result of the provincial and regional elections (LSI 2007, 4). ${ }^{6}$ Five years later (2010), this number rose moderately to 44\% (64 of 146) (Rakyat Merdeka, 26 September 2010). ${ }^{7}$

\footnotetext{
${ }^{5}$ In this research, an incumbent is a person who holds the office as a regent or mayor (not as deputy of regent or mayor) in 2005. Thus, when they contested in the 2010 pilkada, these incumbents had stayed in office for 5 years.

6 Incumbents are regional heads and governors who run for a second election. Indonesia had held 296 regional and provincial elections from June 2005 to December 2006. 230 regional heads and governors ran for pilkada as the candidate of regional heads and governors. Also, 63 incumbents of deputy of regional heads and governors competed for regional head and governor positions in the 2005-2006 pilkada.

7 These data refer to a review of Lembaga Survei Indonesia (The Indonesia Survey Institute) published in Rakyat Merdeka, 26 September 2010.
}

The last two waves of simultaneous pilkada show similar trend. In 2015, 42.1 per cent of incumbents failed to retain their offices contested in 260 pilkada. ${ }^{8}$ In 2017, Research and Development Division of KOMPAS also reported a slight increase of the incumbents' failures to 43.53 per cent (of 101 pilkada). ${ }^{9}$

Inconsistencies between the advantages of the incumbents' favourable position and the re-election results, then, sparked a set of questions to address this political conundrum. What are the factors that lead to re-election? Why are the incumbents, who have access to local government resources and control over bureaucracy, unsuccessful in securing their posts in a re-election? What are the implications of surviving and nonsurviving strategies for democracy? A more detailed understanding of local politics is revealed by examining populist policies and informal politics associated with the incumbents.

\section{East Java Province: The case studies}

\footnotetext{
$8 \quad$ Source: http://print.kompas.com/baca/ 2016/01/06/Petahana-Tetap-Kuat-di-Pilkada2015 accessed on 7 January 2016.

9 Source: http://suarajakarta.co/news/politik/4353persen-petahana-kalah-di-pilkada-2017-berlanjutke-jakarta/ accessed on 3 March 2017
} 
The study was conducted in East Java Province. It took four regions representing rural and urban areas, namely Blitar Regency and Trenggalek Regency (rural) and Probolinggo Municipality and Madiun Municipality (urban). The analysis is focused on the pilkada that took place in 2010 in Blitar and Trenggalek and in 2008 in Probolinggo and Madiun.

This study applied qualitative research principles by interviewing the incumbent regional head, heads of local government offices, NGO activists, women activists, journalists, academics and female voters in two villages, through semi-structured interviews in each region. Specific to voters, the study interviewed about their reasons in the voting process for the incumbents. It also analised local official documents and local budgets (Anggaran Perencanaan dan Belanja Daerah/APBD) in each regional government.

Blitar Regency and Trenggalek Regency are located in the southern part of East Java. The former has 1,116,010 people living in an area of $1,588.79 \mathrm{~km}^{2}$ in 2010. The later covers an area of $1,261.40 \mathrm{~km}^{2}$. The majority of the population in both regencies is Muslim.

Blitar held the first pilkada in 2005. The pair of candidates Herry Noegroho and Arif Fuadi had won the first pilkada with $42.18 \%$ of the votes. Five years later, Herry Noegroho and Arif Fuadi ran separately in their re-election bid (the 2010 pilkada). The incumbent Herry Noegroho succeeded to retain the office with $59.70 \%$ of the votes.

The pilkada in Trenggalek Regency was a battle between two incumbents. In the first pilkada in 2005, the incumbent Soeharto $^{10}$ (2005-2010) defeated the former incumbent Mulyadi WR (20002005). Then, in the re-election bid held on 2 June 2010, the incumbent gained the least votes, only $22.4 \%$ (71.818). Mulyadi collected 174,656 votes (54.4\%) and regained the office (Trenggalek Election Commission, 2010: 79).

Probolinggo and Madiun municipalities are two regions in East Java with small area coverage and less populated. The population in Probolinggo municipality was 226,643 in 2008, living in a total area of $56,667 \mathrm{~km}^{2}$. Madiun Municipality is surrounded by the area of Madiun Regency. The population was 201,619 people in 2008 , living in a total area of $33 \mathrm{~km}^{2}$. The majority of the

10 The incumbent has exactly the same name as the former Indonesian president Soeharto (19661998). So, the name Soeharto throughout this article refers to the former regent of Trenggalek (2005-2010). 
population both in Probolinggo (96.08\%) and Madiun are Muslim (88.78\%).

Probolinggo and Madiun Municipality were two of the regions in East Java which held the pilkada in 2008. In this pilkada, the incumbent mayor of Probolinggo, Buchori defeated two other challengers. The incumbent regained the office by a landslide victory $(72.55 \%$ of the votes). In contrast, the incumbent mayor of Madiun, Kokok Raya, experienced a crushing defeat in reelection bid on 23 October 2008. He gained only 22,521 ballots (25.69\%). The winning challenger, Bambang Irianto, defeated him with the most votes, $53.51 \%$ (46,900 ballots).

\section{THEORETICAL PERSPECTIVES}

\section{Political Survival}

The selectorate theory of Bruce Bueno de Mesquita et al. (2003) is an outstanding work in researching the political survival of national leaders in many countries. De Mesquita examines the groups which exist in all polities, namely the selectorate (the set of people with a say in choosing leaders and with a prospect of gaining access to special privileges doled out by leaders), the winning coalition (the subgroup of the selectorate who maintain incumbents in office and in exchange receive special privileges), leadership (the smallest set of individuals which actually makes decisions about gathering and allocating resources), and the challenger (national leadership and prospective substitute leaders). The position of these groups is changeable related to the leader's political survival. Moreover, the relationship between leaders, followers, and supporters is connected by affinity, or the bonds between leaders and followers that both can use to anticipate each other's future loyalty. The bonds can be influenced by several clustered factors, namely ethnic or religious preferences, personality, ideology, political party identification, experience, family ties and charisma (de Mesquita et al., 2003).

The dynamics of leader tenure in office are reflections of selection institutions driven by the provision of public and private goods. The selectorate theory first assumes the impact of the vagaries of the economy on the available resources allocated by the leader. The second argument focuses on the leaders as well as the competence of politicians and challengers in producing goods from the given resources. More competent leaders will produce more goods in the 
future for members of their winning and vision to the voters and achieve a coalition.

level of popularity and trust in the eyes of

The next arguments assume affinities local people. The non-surviving between leaders and followers. The incumbents are considered to be argument assumes that interactions punished by voters for failing to deliver between both parties can reveal their public benefits in their first term; voters bonds and the future loyalties of the vote in a "rational" manner; major political selectorate, based on the possibility of being included in or excluded from the winning coalition and the benefits of private goods for the winning coalition. The last argument assumes that all affinities are known by the selectorate, the winning coalition, the incumbent, and the challenger. The selectorate can calculate their chances of being included in the winning coalition of the challenger if it comes to power (de Mesquita et al. 2003).

Particular to the pilkada case in Indonesia, Erb and Sulistiyanto (2009) elaborate several factors that may lead to the incumbents' survival and failure, based on collective works covering Indonesia and specific works in six provinces and 13 regions. For the incumbents to survive, they need to do very well in their first term in office; gain support from a coalition of major political parties; organise campaign teams and grass-roots support groups during the campaign period; offer the best programs

\section{CONTEXT: FINDINGS AND DISCUSSION The Search for Political Credits}

The case study in four rural and urban regions points out that all incumbents performed populist politics during the first term in office. Populist politics is divided into two categories, 
namely populist policies and popular activities which are familiar amongst local elites and people. In the former category, the incumbents pursued similar policies delivering direct and tangible benefits, such as death benefits, free or cheap health services, free or cheap education fees, scholarships for poor pupils, infrastructure developments, mainly roads, at the neighbourhood level, city garden improvements, friendly policies for street vendors (PKL) and pedicab drivers (abang becak), cheap groceries markets, and huge infrastructure projects. The incumbent in Madiun Municipality even initiated the implementation of a local government-funded program of regional health insurance (Jamkesda) in 2008. The insurance covers the poor in the municipality who are not covered by the national health insurance (Jamkesmas).

To finance these policy choices, local governments under the incumbents' leadership allocated higher budgets for education, health and public works compared to other regencies and municipalities in the province. Trenggalek Regency is an exception, allocating a lower local budget $(A P B D)$, spending $9.45 \%$ on average within five years (2006-2010) on public works compared to the regencies' average of $11.75 \%$.
Populist policies are not merely intended to benefit the majority of local people. The incumbents also delivered direct benefits to bureaucrats. All incumbents disbursed additional financial incentives and rice benefits for bureaucrats, except the incumbent in Trenggalek. In addition, financial benefits were distributed to the heads of villages and the heads of hamlets (heads of neighbourhood units and community units) in Blitar Regency and Madiun and Probolinggo Municipalities. The incumbent in Blitar also provided service motorcycles for all heads of villages.

The impact on local development can be measured by human-related development achievements. The case study in four regions found a similar trend towards a lower infant mortality rate, better life expectancy index, economic growth, purchasing power parity index and finally the human development index (HDI). Nevertheless, these similar or even better wellbeing conditions did not assist incumbents to survive. Comparative assessments of $\mathrm{HDI}$ in the regions where the incumbents failed in the pilkada, indeed, were better than the regions where they survived. Blitar Regency under the surviving incumbent's leadership reduced the regency's HDI shortfall by 
1.54 over 5 years (2006-2010), lower neighbourhoods. The incumbent in than Trenggalek Regency, which achieved Probolinggo Municipality performed 1.62. Nonetheless, the incumbent in blusukan almost every day, accompanied Trenggalek Regency did not succeed in by a village head from where he visited. the re-election bid. Also, in the last year of After praying shubuh (early morning the incumbent's office (2008), Madiun Municipality had a better HDI (75.89) than Probolinggo Municipality (73.29). However, this better wellbeing indicator did not help the incumbent to succeed in the 2008 pilkada.

In addition to carrying out popular policies, all incumbents were burdened by corruption cases alleged against them or their staff. An exception was the incumbent in Blitar, as corruption allegations were disclosed in 2012 or two years after he was re-elected for the second term.

Blusukan (impromptu visit; visiting community meeting points) was the most common popular activity of the incumbents in four rural and urban regions. They frequently visited community meeting points to directly connect with ordinary people in the regions, such as at traditional markets, mosques, and neighbourhoods. The incumbents directly interacted with local people to hear their problems and complaints on local government services or people's aspirations to develop their prayers), he visited community spots to interact directly with local people. The incumbent in Madiun Municipality also performed blusukan, especially at traditional markets and neighbourhoods. Local people interviewed in both urban regions testified that both incumbents seemed to blend in with ordinary people. The incumbents dispensed with protocol and even frequently wore sportswear when interacting with ordinary people.

The incumbents in Blitar and Trenggalek Regency were also publicly known as down-to-earth figures. They interacted directly with villagers in nonformal activities, such as pengajian, ${ }^{11}$ wayangan (shadow puppet show), sports events, harvest festivals, fishermen" festivals, and other popular activities. The incumbent in Blitar Regency even took on the post of manager and chair of PSBI (Blitar Soccer Association). This activity made him very popular amongst the youth or PSBl's supporters. They called

11 A gathering at which Islam is discussed (Stevens and Schmidgall-Tellings, 2010, p. 238) 
the incumbent "Bapake Singo Lodro" (the main instrument to provide incentives, father of cruel lion). ${ }^{12}$ mainly for informal actors. The case

Takziah (to visit, to deliver studies in four regions found six condolences) was another popular activity categories of actors involved in supporting which is well-known amongst local as well as gaining benefits from the people in Probolinggo and Madiun. In incumbents prior to the pilkada. These addition to paying condolence calls to categories are based on two main bereaved families, both incumbents gave indicators. First is the impact of donations. Blusukan and Takziah are two relationships between the incumbents and of the most prominent popular activities informal actors on the incumbents' amongst local people in the two survival. Informal actors' activities to municipalities.

Popular activities performed by the support the incumbents may impact on incumbents in all regions are one method their electability. These include the donation and disbursement of campaign to market the incumbents' well-liked funds, campaign materials, and images amongst ordinary people. This philanthropically biased activities by could be called "egalitarian branding". businessmen, which have an impact on These local leaders attempted to counter the improvement of the incumbents' the preceding elitist leadership style electability. At the same time, adopted by leaders under the new order businessmen have put the incumbents in (Soeharto) regime. Also, by their transactional contracts to return what they willingness to interact directly with have already spent by demanding rewards ordinary people, the incumbents sought to in terms of project implementation. Next blend their personal identities with the is the degree of relationship between the communal identity and expected to attract incumbents and informal (or partisan people's sympathy.

formal) actors. A good relationship impacts on low political rivalry risks for

\section{Minimising Political Rivalry Risks}

To perform the politics of the incumbents.

particularism, the incumbents particularly informal politics on voters (grassroots utilised the local budget (APBD) as the effect) is emerged in the electability effect.

12 Singo Lodro is the nickname of PSBI. It is the result of informal political 
practices undertaken by the actors for the incumbents' popularity as well as likeability amongst local people.

The second indicator shows the impact of informal politics on elites (elite effect). Rivalry risk is the result of informal connections between incumbents and actors. Supporting relationships between both parties could minimise the risks of political rivalry from informal actors to the incumbent. In this situation, incumbents could prevent potential resistance from actors as well as their impact on the grassroots. As part of the elite, actors have resources to discourage people to vote for the incumbents or to undermine the incumbents' electability.

Businessmen $^{13}$ are the most common informal actors connected to the incumbents, pertaining to the pilkada in four regions. They are particularly local contractors who implement physical local government projects, such as infrastructure and local government funded buildings. The case study in four regions recognises these businessmen as tim konstruksi (the construction team). Local businessmen donated individually or in a group by participating in some charitable programs, both conducted by

\footnotetext{
13 It is rare to find any businesswoman involved in supporting the incumbents in the four regions.
}

the incumbents and local governments, such as cheap markets for groceries, incidental free health services, sports events, and religious events.

The second crucial actors are local bureaucrats. It is actually inappropriate to categorise bureaucrats as informal actors relating to the pilkada. Nonetheless, the case study asserts that not all informal actors are non-government persons. Partisan bureaucrats who supported the incumbents were found. They are categorised as informal actors' due to their role in supporting the incumbent by using formal institutions. However, their activities are not only intended to implement local government policy, but they also intentionally design policies favouring the incumbents. Thus, bureaucrats are included as formal actors playing informal politics to support or undermine the incumbents. Control over bureaucrats is very important for the incumbents to minimise the risk of political rivalry.

Comparative assessments of four regions explain a convergent fact that local legislators ${ }^{14}$ play an important role in supporting the incumbents in maintaining office. The legislators secure the

14 Like local bureaucrats, local legislators are formal actors who play incentives (local budget) to negotiate with the incumbent. 
incumbents' policy choices in the local legislative body. They particularly support the incumbents' policy proposals in the budgeting process. The incumbents in Blitar and Probolinggo gained strong support from, mainly, the Indonesian Democratic Party of Struggle (PDI-P)'s faction in the local legislature.

Partisan NGOs or grassroots organisations are also important informal actors that may support or undermine the incumbent in office. In order to counter critics, the incumbent's party backbone (PDI-P) in Probolinggo expanded its network to cover local NGOs, the street vendors' ( $P K L)$ association and the pedicab drivers' association. They collaborated to perform counter movements for every issue or organisation seeking to undermine the incumbent. To make these networks work, the incumbent created certain policies and programs which delivered direct advantages for them, such as friendly and charitable policies for PKL and pedicab drivers and opening opportunities for partisan NGOs to implement local government's social projects (project assistance). These networks were also effective in hampering the money politics undertaken by the challenger in the 2008 pilkada.
Finally, solid party support was also important for the incumbents prior to the pilkada. Less conflicting coalitions of parties succeeded in backing up the incumbents in Blitar and Probolinggo. Nevertheless, internal conflict amongst coalition party members in Trenggalek undermined the incumbent's control over party elites. The conflict, then, led to party elites shifting support to the winning challenger. Less supportive coalition party members also reduced the strength of the party machine in mobilising their followers to vote for the incumbent. In addition, limited party support (PDI-P only) for the incumbent in Madiun was not adequate to promote the incumbent's well-liked image amongst voters. A noncoalition party, such as in Madiun, also limited its capacity to detect and prevent the money politics disbursed by the winning challengers. Therefore, political parties' roles are not only limited to meeting candidacy requirements, but are also important to expand supporter bases and to maintain their loyalties, through implementing parties' policies to support incumbents.

In addition to these five categories of actors, the case study also identified other actors supporting the incumbents in the pilkada, namely kiais (Islamic religious 
Table 1 Voters' Considerations

\begin{tabular}{|c|c|c|c|}
\hline \multirow[t]{2}{*}{ Reasons } & \multicolumn{2}{|c|}{$\begin{array}{l}\text { Vote or not to Vote for the } \\
\text { Incumbents }\end{array}$} & \multirow[t]{2}{*}{ Tangible Aspects (or notes) } \\
\hline & Surviving & Non-surviving & \\
\hline $\begin{array}{l}\text { Tangible policy } \\
\text { outputs }\end{array}$ & Yes & Yes & $\begin{array}{l}\text { - Infrastructure } \\
\text { - Goods } \\
\text { - Money politics (undermines policy effects) }\end{array}$ \\
\hline $\begin{array}{l}\text { Popular image } \\
\text { (clean and good } \\
\text { person) }\end{array}$ & Yes & Yes & $\begin{array}{l}\text { - Donations } \\
\text { - Direct interaction or appearance }\end{array}$ \\
\hline $\begin{array}{l}\text { Competitive } \\
\text { advantage }\end{array}$ & Yes & $\begin{array}{l}\text { Yes (minus } \\
\text { Madiun } \\
\text { Municipality) }\end{array}$ & $\begin{array}{l}\text { - To sustain tangible and direct policy } \\
\text { benefits }\end{array}$ \\
\hline $\begin{array}{l}\text { Party ID/figure } \\
\text { alignment }\end{array}$ & Yes & Yes & $\begin{array}{l}\text { - PDIP and Democratic Party's loyalists } \\
\text { - Emotional connection }\end{array}$ \\
\hline $\begin{array}{l}\text { Anut grubyuk (fitting } \\
\text { in) and ignorance } \\
\text { (rural regions) }\end{array}$ & Yes & Yes & $\begin{array}{l}\text { To give both advantage and disadvantage to } \\
\text { the incumbents }\end{array}$ \\
\hline
\end{tabular}

leaders), pesantren (Islamic boarding corroborations mainly address the tangible school), and PKK (family welfare aspects of the policies and image of the movement). Except in Madiun, all incumbents.

incumbents in Blitar, Trenggalek, and The case studies in four rural and Probolinggo had close relationships with urban regions found five categories of kiais and pesantren. Nonetheless, not all motives that shaped voters' preferences to incumbents retained their posts. Except in vote or not to vote for the incumbents. As Probolinggo, the relationship between the seen in table 1, firstly, voters referred to incumbents and kiais was not publicly the tangible policy outputs credited to the apparent. There is insufficient academic incumbent. Better infrastructure (roads) at evidence to support claims about the neighbourhood level was mostly transactional relationships between the recognised by voters in the four regions. incumbents and kiais and pesantren.

\section{Fast Food Politics}

Voters' reasons to vote or not to vote for the incumbents can verify the logic of populism and informal politics for the incumbents' survival. However, the case study points out that these voter's

Secondly, complementary to the tangible and direct policy outputs are the popular images of the incumbents. The incumbent's activities of so-called blusukan and takziah in Probolinggo Municipality were clearly remembered by voters. They frequently mentioned them as extraordinary activities performed by a 
person who held the most honourable and prominent position in the municipality. This admiration persuaded voters to vote for the incumbent.

Thirdly, voters compared the incumbent and the challenger before making decisions. The basis of comparison was the competitive advantage between candidates. This argument was mainly delivered by voters who possessed leadership positions in the community, namely hamlet heads, neighbourhood unit (RT) heads, community unit (RW) heads and village heads. They voted for the incumbents in Blitar Regency and Probolinggo because they perceived that the incumbents were more experienced and well-grounded than the challengers. Many of the incumbents' programs were not yet completed in the first term. They voted for the incumbents because they considered that the previous advantageous programs should be continued in the second term. By voting for the incumbents, these elite voters sought to minimise the uncertainty risks. The case study in Blitar found a Javanese proverb to express this consideration, "timbanganne nggolek wong nembel or timbang bakal aluwung nambal' (rather than finding a new leader).
Fourthly, some voters considered party loyalty (party ID) when deciding whether to vote or not to vote for the incumbents. Voters' alignment to a certain party that nominated the candidate shaped their preference. Voters obeyed the party's decision and voted for the nominated candidate. Finally, the case study in two rural regions (Blitar and Trenggalek) found voters practising anut grubyuk (fitting in) in the voting process. Voters adjusted their preference to the majority or growing opinion in the neighbourhood. Voters in Blitar mainly practised anut grubyuk to vote for the incumbent. Voters in Trenggalek performed anut grubyuk to vote or not to vote for the incumbent. Thus, anut grubyuk both favoured and disfavoured the incumbents.

These five categories of voters' explanations corroborate the logic of the incumbents' survival as explained by elites (local government officials, NGO activists, journalists, party activists, businessmen, political consultants and the former regents and mayors) interviewed in the case studies. Populist policies and activities giving direct and tangible benefits to voters shaped their decision to vote, including money politics disbursed by the winning challenger's 
camp in Madiun Municipality. their tray at the counter, finds a table, Nevertheless, voters could not identify the takes a seat, unwraps the paper, and digs informal political actors who delivered in" (Schlosser, 2002).

benefits or goods to them. The benefits

The analogy of consuming fast food is were usually distributed by the plausibly appropriate to explain voting intermediary or in the name of the behaviour (to vote or not to vote for the incumbent. Voters, then, praised the benefits given by the incumbents.

In these case studies, decisions to vote or not to vote for the incumbents in the pilkada are mainly encouraged by the tangible aspects of policy outputs. Voters were not likely to consider intangibles with long-term benefits or policy outcomes, such as the human development achievements of health, education, and economy (well-being). To develop a more abstract conception of this sort of voting behaviour, the analogy of consuming fast food can be applied. The food is usually served in a comfortable place, modern, of eye-catching appearance, put into a clear menu and creatively wrapped. Then, the main reason to buy fast food is because most of it tastes quite good, is inexpensive and convenient (giving a distorted sense of how much it actually costs), "without giving it much thought, rarely considering where this food comes from, how it was made, what it is doing to the community around them". The consumer "just grabs incumbents) in the pilkada in these four rural and urban regions. Firstly, the majority of voters quickly judged their decision to vote or not to vote for the incumbents, without much thought, based on superficial policy outputs (visible, noticeable, direct and short-term benefits). Secondly, they considered the eye-catching appearance of the incumbents, such as their generosity and humility. This demonstrates the importance of the incumbents' personal marketing (image) and personalisation of policy outputs (political credit).

\section{The Comparative Logic of Survival and Failure}

There are three interrelated themes concerning the logic of the incumbents' survival and failure in the pilkada. First is populism. This is not only about political ideas which are intended to represent ordinary people's needs and wishes. This also covers populist policies and popular activities which the incumbents were praised for. 
Populism works to construct a well- incumbents. The incumbents' capacity to liked image of the incumbents amongst manage these actors via mutual local people. In detail, populist ideas, transactional relationships is central to policies and popular activities are discouraging counter-movements that personal marketing for the incumbents to may undermine the incumbents' influence make them appear as popular figures. They act apparently as figures who care or amongst local people.

The last theme is tangibility or the give very much attention to common people's concerns (problems, needs, and wishes). Moreover, populism functions as the result of the personalisation of (populist) policy outputs. The successful incumbents do solo runs to maximise public praise and develop their well-liked image via the implementation of populist policies.

Second is rivalry. Embracing informal actors and partisan formal actors was crucial for the incumbents to survive. They are a group of local elites consisting of businessmen, partisan bureaucrats, legislators, party elites, and partisan NGOs (and media) providing support for the incumbents to stay in office. They operate to particularly minimise political rivalry risks to the incumbents. This concept is adaptable, representing the operation of the actors playing informal politics with the assurance of transactional relationships as incentives. These actors perform either encouraging or undermining activities for the ability to deliver tangible aspects of policy outputs and appearances, credited to the incumbents during office. Tangible and direct policy outputs are remembered and shape voters' preferences to vote for the incumbents in the pilkada, such as infrastructure at the neighbourhood level, city gardens, subsidised or free groceries and other donations praised to the incumbents. Not only in deciding to vote for the surviving incumbents, the case studies in Trenggalek Regency and Madiun Municipality pointed out that voters, including female voters, considered these policy outputs when deciding to vote for the non-surviving incumbents. To be specific, in Madiun Municipality, the cash disbursed by the winning challenger's camp also shaped voters' preferences not to vote for the incumbent.

Complementary to tangible policy outputs are noticeable appearances of the incumbent amongst local people. Blusukan and takziah are the two most 
popular activities remembered and adored by voters. These activities contributed to the improvement of voters' likeability or affinity towards the incumbents. The existence of these three factors attached to the incumbents is crucial to explain the logic of their survival or failure. The comparison shows that the incumbent in Blitar and Probolinggo succeeded in performing populism and tangibility and in managing the low rivalry risks from informal and partisan formal actors prior to the pilkada. The incumbents in Trenggalek and Madiun actually succeeded in promoting populism and tangibility to the local people. Nonetheless, their failure to control informal politics and actors compelled the incumbents to leave their posts.

In the case studies, the low rivalry risks from informal politics can explain the logic of the incumbent's survival and failure in the pilkada. Good populism and tangibility fulfillment will support the incumbents in gaining credit from local people. Nevertheless, the politics of particularism via incentives, playing between the incumbents and five categories of local elites, were strong enough to minimise the risks of political rivalry that may undermine the incumbents' influence (populism and tangibility) and to block money politics attacks on potential voters.

Thus, the rivalry risks from informal and partisan formal actors, which depend on the degree of informal political maneuvers played out between the incumbents and these actors, are likely to determine the incumbents' survivability, even though the incumbents have similar competitive advantages of populism and tangibility.

\section{Making Democracy Valuable}

For those studying local politics and democracy in Indonesia, the implementation of the pilkada in 2005 sparked critical concern about serious challenges for the emerging democracy, following democratic reforms begun just seven years earlier (1998). The dramatic end of the 32 years of an authoritarian regime, followed by rapid political change, still leaves questions about democratic consolidation thereafter. A logical question mainly addressed by political scholars pertains to the change in democracy in Indonesia, including at the local level. Does the pilkada encourage the progress of local democracy? What are the enabling or preventing factors for local democracy to move on? The previous collective works provide evidence that the pilkada is a step 
that will help to deepen democracy (Erb to deal with the acceptance of democratic and Sulistiyanto, 2009). Nonetheless, constitutional order amongst sharia state's other works find difficulty in generalising supporters, worrying levels of behavioural, local politics in post-Soeharto Indonesia, attitudinal and constitutional commitment as there are various democracy outputs in to democracy from key elites, poor diverse regions (Aspinall and Mietzner, performance of corruption and the rule of 2010). Also, a local democracy study in law and the combination of four provinces (East Java, West Sumatera, presidentialism and a multi-party system South Sulawesi and Bali) asserts that that may lead to unstable democracy local elites' interests, focusing only on (Diamond, 2010). From the examination gaining power, have undermined the of voting behaviour data in a series positive contribution of the pilkada to (1999-2009) of legislative and democratic institutionalisation (Zuhro et presidential elections, Mujani and Liddle al., 2011). Essentially, there is no single explanation of the progress of local democracy in post-Soeharto Indonesia. This research adds more detailed content on incumbents' political survival (regional heads) in an electoral democracy. Moreover, it seeks to assert that certain parties have a strong interest in "manipulating" local democracy.

By referring to Freedom House's measure of democratisation, based on the assessment of the quality of civil rights and civil liberties, Aspinall and Mietzner have put Indonesia's democracy into the consolidation perspective (2010). Other works in the same publication edited by these Indonesianists apply a similar perspective. The consolidation of Indonesia's democracy still has a struggle (2010) explain Indonesia's democracy consolidation and quality with both positive and negative aspects of voting behaviour. The similar perspective is also applied by Zuhro et al. (2011) to construct a model of local democracy in Indonesia.

Specific to reviewing the pilkada in the regions, other collective works $^{15}$ concluded that the implementation of local elections in Indonesia is problematic in terms of democratic consolidation. The pilkada is coloured by weaknesses, namely a lack of impartiality and independence of local general election commissions, some violence, huge numbers of absentees and domination by dynamics of the first round pilkada in 2005. 
political parties (Erb and Sulistiyanto, 2009).

Nevertheless, consolidation as a perspective to 'measure' democratisation of a country or countries is not without criticism. As a cluster concept, consolidation is structurally understandable but without a core. The division of democratic types, liberal and electoral democracy, to classify either democratic survival or democratic progress in democratic consolidation does not have common ideas. As a result, the consolidation of democracy seems to act as a catch-all concept, lacking a core meaning to unite all modes of usage. Thus, "consolidology" is only a label for the study of new democracies. However, academic communities deploy the term democratic consolidation in whatever ways best fit for research, funding needs, and advertising strategies (Schendler, 1998). The consolidation perspective is also very formally oriented. It sets the criterion of formality based on "a close fit between formal rules and actual behaviour". In fact, some countries with long traditions of democracy, such as Italy, Japan and India are rampant with the practices of particularism which are informal in character (O'Donnel, 1996).
From the examination of political survival and failure at the regional levels, this study asserts that rivalry is a crosscutting factor that may support the incumbents' survival or failure in the pilkada. In other words, a good incumbents' performance in delivering populist policy outputs and appearance with tangible and direct benefits is not adequate without obtaining backing and protection from informal and partisan formal actors.

This finding arrives at a crucial argument that the pilkada is captured predominantly by local elites. The degree of political rivalry on the incumbents, as an explanatory aspect of their survival and failure, is assumed to have a poor impact on the pilkada outcomes. The pilkada has not yet delivered its main mission as a competitive mechanism of democracy to encourage better local leadership, with positive effects on local development achievements. The domination of elites and less critical voters possibly became one of the factors that potentially caused local development losses. Informal and partisan formal actors transacted their influence and resources to gain individual and constituent-based benefits. They amused local people with short-term, 
practical and popular development outputs.

Democracy is not solely about election concerns. Thus, electoral accountability or democratic accountability is the crucial idea of the democratic spirit. ${ }^{16}$ Election and succession are mechanisms to select better leaderships that are able to deliver equal advancement and benefits for all people. Schumpeter fundamentally contends that the classical doctrine of democracy is about the common good and the will of the people. "The democratic method is that institutional arrangement for arriving at political decisions which realizes the common good by making the people itself decide issues through the election of individuals who are to assemble in order to carry out its will" (Schumpeter, 1950). Therefore, democracy is a competitive method to amass collective interest, aggregated in political decisions (policies) and mandated to the elected leaders. This doctrine clearly underlines the idea of the electoral accountability of the elected leader to carry out the common good and the will of the people.

16 This study uses the concept of electoral accountability and democratic accountability interchangeably. Both concepts have identical meanings.
Moreover, Dahl warns that democratic government under elected competitive leadership is accountable for translating these advantages into realities (1998). Based on these quantitative and grounded data from the field, relating to the pilkada and its impacts, this study proposes an alternative idea to review democratisation, not from the perspective of inquiring into the facts and reasons for what makes democracy work, in terms of the consolidation of democracy. In the emerging stages of democracy, especially at the local level, democratic progress should be viewed from the outcome perspective, to shape the will of the people. In the early stage of democracy in Indonesia, democracy as a constitutional choice needs to gain a quick win or impressive effect as a better alternative than any other form of non-democratic government. The confidence and trust of the people in local democratic government can only be obtained through the better performance and outcomes of democratic government under competitive elected leadership.

Here, it is assumed that electoral accountability is appropriate and complementary to other existing perspectives of democratisation, particularly the consolidation of 
democracy. The logic of endorsing democratic accountability to measure democratic progress in the pilkada, complementary to democratisation, firstly, relies on the argument of institutional arrangement and accountable and democratic local government. The pilkada follows the logic of the presidential government system (presidentialism) in electing a leader. Under presidentialism, asking the government to be accountable to voters becomes possible. An incumbent leader is an easy target for voters to evaluate this leader's performance (Hellwig and Samuels, 2008).

Secondly, democratic accountability is important to consider as a complementary perspective to democratisation, since Indonesian democracy is not sufficiently understood through institutionalism only. In other words, institutional arrangements matter in shaping behaviour and policy, as in the first argument; nevertheless, non-institutional or informal factors have crucial roles in performing similar functions as formal institutions.

Thus, comprehending Indonesian political dynamics relies both on formal institutions (law, constitution, formal institutions, institutional arrangements) and informal factors (non-codified norms, value, actual praxis, beliefs). This study demonstrates the importance of informal politics, which more significantly determined the political survival of regional heads in the pilkada. Democratic accountability as a complementary perspective is appropriate to comprehend democratic progress, as it may identify to whom an elected leader gives more response, whether to the large number of constituents or the small number of loyal and supportive elites.

\section{CONCLUSION}

\section{Expanding the Logic}

The study makes contributions to the literature on the theory of political survival (de Mesquita et al., 2003). The study, first, enriches the concept of tangibility to better understand the selectorate's voting behaviour. The research argues that not all voters can identify the incumbents' populism (policies and activities); some voters even intentionally ignore it. Thus, tangibility, that delivers the concrete aspects of policy outputs and popular appearance which are credited to incumbents, contributes to shaping voters' preferences to vote or not to vote for the incumbents in re-election bids. Also, the study introduces the concept of rivalry, to represent the operation of the actors who play informal politics that may encourage 
or undermine the incumbents' survival in (preferences and reasons) in the pilkada, the pilkada. Informal politics is the play of mainly pertaining to populism and the politics of particularism that can bond tangibility.

incumbents and informal and partisan formal actors and voters.

Secondly, the study revised the concept of provision of public goods that contribute to the leaders' survival. The case studies find specific goods were considered by voters in deciding to vote or not to vote for the incumbents in the pilkada, namely tangible goods, such as infrastructure, but not intangible wellbeing aspects, such as improvements in health, education and local economy. The concept of public goods also becomes blurred as a result of the politics of particularism played by the incumbents and informal and partisan formal actors.

Thirdly, the study criticizes the rational assumption of the selectorate theory about the possession of information on economic downturns, leaders' competence and the competitive advantage of the incumbents and challengers amongst voters. In fact, the majority of voters neglected these aspects. They strongly recalled and considered tangible aspects of policy outputs and the popular appearance of the incumbents. The study also enriches narrative explanations of voting behaviour
Specific to the preceding literature on the pilkada in Indonesia, Sulistiyanto (2009) argues that factors leading to the incumbent's survival in the pilkada are different in each region. Arguably, this study finds that populism, rivalry and tangibility are similar factors that could contribute to the incumbent's survival or failure in many pilkada. This study also expands Erb and Sulistiyanto's (2009) arguments about local leaders' survival in the pilkada. It proposes the significance of informal politics and networks in the pilkada as instruments to minimise the risks of political rivalry to the incumbent, mainly from informal and partisan formal actors.

To the literature on voting behaviour, mainly for Javanese voters, this research reveals a genuine concept of anut grubyuk (fitting-in) in voting decisions in rural Java. This study finds anut grubyuk as a unique group-based voting preference amongst rural Javanese that cannot be separated from Javanese communal culture (philosophies and values).

Additionally, the preceding theory on Javanese voters states that norms and values shape partisan choices amongst 
Javanese villagers. Rural Javanese voters emphasises democratic consolidation. express these norms and values mainly in Electoral accountability offers countries in two of three prominent aliran the emerging stage of democracy an (mainstreams), namely abangan (who outcome perspective of democracy in follow the Hinduistic element in Javanese shaping the will of the people (making tradition) and santri (who take as their democracy valuable). It argues that, in main pattern a way of life orientation, a addition to sustained democratic progress, set of beliefs, values and expressive an emerging democratic country needs symbols based primarily on Islamic impressive effects of democracy as a doctrine) (Gaffar, 1992). Nonetheless, better alternative government than any anut grubyuk in the pilkada shows a other forms of non-democratic distinctive explanation of rural Javanese government. Democratic accountability voters. Anut grubyuk demonstrates, firstly, shows that a leader who is elected voters' rational behaviour in gaining competitively chair a democratic benefit from collective voting decisions in government, to meet the common good the neighbourhood that could be bartered for particular incentives from the incumbents and overcomes the limitation of information to support voters' decisions to vote or not to vote for the incumbents. Secondly, it also shows that the level of democratic processes in Indonesia have not yet been able to provide equal freedom to vote independently for every voter.

To the literature on democracy, this study offers a complementary perspective to measure the progress of democracy by inserting electoral or democratic and the will of the people.

Thus, based on the case study findings, the study recommends further practical work to examine the possibility of the inclusion of democratic or electoral accountability in composing the Indonesia Democracy Index (IDI). IDI is a provincially based measurement of democratic progress focused on three main aspects, namely civil liberties, political rights, and institutions of democracy (Rauf et al., 2011). IDI emphasises the application of a consolidation perspective to measure the accountability. The concept further irreversible progress of democracy. Thus, develops the inquiry into democracy in this study recommends that IDI needs to the emerging democratic countries that incorporate electoral accountability, as 
complementary to this perspective, in order to broaden the assessment, to not only ensure making democracy work, but also making democracy valuable. IDI could probably add a new aspect of measurement, to assess people's perceptions of the performance of local elected leaders as well as legislators.

What, then, the prospect of Indonesian democracy? In the middle term, there will be some incremental improvements, mainly in the pilkada. However, informal politics will remain occur and capture the pilkada and democracy.

\section{REFERENCES}

Aspinall, E and Mietzner, M. (Eds)/ 2010. Problems of Democratisation in Indonesia: Elections, Institutions, and Society. Singapore: ISEAS Publishing.

Besley, T and A. Case. (1995). Incumbent Behavior: Vote-Seeking, Tax-Setting, and Yardstick Competition. The American Economic Review, Vol. 85 No. 1.

Dahl, RA. (1998). On Democracy. New Haven: Yale University Press.

Dahlberg, M and E. Johansson. (2002). On the Vote-Purchasing Behavior of Incumbent Governments.
American Political Science Review, Vol. 96 No. 1.

De Mesquita, BB, Alastair Smith, Randolph M. Siverson, and James D. Morrow. (2003). The Logic of Political Survival. Cambridge: The MIT Press.

Diamond, Larry. (2010). Indonesia's

Place in Global Democracy.

Erb, M. and Sulistiyanto, P. (Eds)/ 2009.

Deepening Democracy in

Indonesia? Direct Elections for

Local Leaders (Pilkada).

Singapore: ISEAS Publishing.

Gaffar, A. (1992). Javanese Voters: A

Case Study of Election under a Hegemonic Party System. Yogyakarta: Gadjah Mada University Press.

Hellwig, T. and Samuels, D. (2008). Electoral Accountability and the Variety of Democratic Regimes. British Journal of Political Science, Vol. 38 No. 1.

Hidayat, S. (2009). Pilkada, Money Politics and the Dangers of "Informal Governance" Practices.

Lingkaran Survei Indonesia Monthly Review. (2007). 2nd edition June. 
Mujani, S. and Liddle, W. R. (2010). Voters and the New Indonesian Democracy.

Nurprojo, I. (2016). Bagongan, Pilkada Serentak dan Demokrasi yang Cedera: $\quad$ Belajar dari Purbalingga. Politik Indonesia: Indonesian Political Science Review, 1(2), 120-135.

O'Donnel, G. (1996). Illusions About Consolidation. Journal of Democracy, Vol. 7 No. 2.

Rakyat Merdeka. 26 September, 2010. Mayoritas Pilkada Masih Dimenangkan Incumbent, p. 3.

Ratnawati, T. (2009). Gender and Reform in Indonesian Politics: The Case of a Javanese Woman Bupati.

Rauf, M., Hidayat, S., Gismar, A.M, and Mulia, S. M. (2011). Indeks Demokrasi Indonesia 2011. Jakarta: UNDP.

Rofieq, A., \& Nuryono, R. (2016). Pengaruh Klientilisme terhadap Perilaku Pemilih Masyarakat Kecamatan Sukatani pada Pilkada Kabupaten Bekasi 2012. Politik Indonesia: Indonesian Political Science Review, 1(2), 105-119.
Schendler, A. (1998). What is Democratic Consolidation?. Journal of Democracy, Vol. 9 No. 2.

Schiller, J. (2009). Electing Regional Heads in Indonesia: Democratic Deepening or Elite Entrenchment?

Schlosser, E. (2002). Fast Food Nation: What the All-American Meal is Doing to the World. London: Penguin Books.

Schumpeter, J. A. (1950). Capitalism, Socialism, and Democracy. New York: Harper and Brothers Publishers.

Sulistiyanto, P. (2009). Pilkada in Bantul District: Incumbent, Populism and the Decline of Royal Power.

Trenggalek Election Commission. 2010. Laporan Penyelenggaraan Pemilihan Umum Kepala Daerah dan Wakil Kepala Daerah Kabupaten Trenggalek Tahun 2010. Trenggalek: Trenggalek Election Commission.

Zuhro, R. S., Legowo, T., and Prasodjo, E. (2011). Model Demokrasi Lokal di Indonesia. Jakarta: The Habibie Centre. 